\title{
Neopatrimonialismo, diferenciação funcional e a relação centro-periferia revisitada
}

\author{
Marcos Abraão Ribeiro' \\ Roberto Dutra ${ }^{2}$
}

\section{Resumo}

Este artigo tem o objetivo de negar a validade teórica do conceito de neopatrimonialismo, formulado por Simon Schwartzman, para compreender os dilemas de exclusão política do Brasil contemporâneo, pois o conceito é baseado em uma leitura apologética do diagnóstico de Max Weber sobre o Ocidente. A partir da análise bibliográfica, defendemos que o conceito de neopatrimonialismo está preso a uma visão empírica e teoricamente insustentável da modernidade política, que idealiza a dimensão democrática e constitucional do poder político moderno e ignora sua dimensão autocrática e não constitucional. Em seguida, apresentamos como alternativa teórica a sociologia política de Niklas Luhmann, pois descreve a política moderna como dividida nos circuitos de poder formal e constitucional, e informal e não constitucional. Dessa forma, podemos analisar os processos de exclusão política no centro e na periferia sem a presença de idealizações sobre os países centrais.

Palavras-chave: Neopatrimonialismo. Diferenciação da sociedade. Modernidade Política. Exclusão.

\footnotetext{
I Doutor em Sociologia Política pelo Programa de pós-Graduação em Sociologia Política (PPGSP) da Universidade Estadual do Norte Fluminense Darcy Ribeiro (UENF) e professor do Instituto Federal Fluminense (IFF) campus Campos Centro. E-mail: olamarcos@yahoo.com.br

2 Doutor em sociologia pela Humboldt Universität zu Berlin. Professor Associado da Universidade Estadual do Norte Fluminense Darcy Ribeiro (UENF). E-mail: robertodtj@gmail.com.
}

\section{(c))Er}

Direito autoral e licença de uso: Este artigo está licenciado sob uma Licença Creative Commons. Com essa licença você pode compartilhar, adaptar, para qualquer fim, desde que atribua a autoria da obra, forneça um link para a licença, e indicar se foram feitas alterações. 


\section{Introdução}

A condução do Estado brasileiro ainda é um tema central entre nossos intelectuais ${ }^{3}$. O processo de apropriação do público por interesses pessoais ${ }^{4}$ ganhou notoriedade com o conceito de "patrimonialismo", que demarca uma força tradicional de dominação política que seria o grande entrave para a modernidade se institucionalizar no Brasil ${ }^{5}$.

Para demarcar a utilização do conceito de "patrimonialismo" podemos tomar como referências as obras de Sérgio Buarque de Holanda ([1936] 1995), Raymundo Faoro ([1975] 2008), Antonio Paim (1998), Fernando Henrique Cardoso (2003), Fernando Uricoechea (1978), Florestan Fernandes (2006), Simon Schwartzman (1975) entre outros, que demonstram como a utilização do conceito derivado da sociologia da dominação weberiana foi bastante difundida entre nossos intelectuais.

O conceito de "neopatrimonialismo", por sua vez, tem sua formulação realizada pelo trabalho de Simon Schwartzman em seu livro Bases do Autoritarismo Brasileiro, no qual o sociólogo mineiro defende que o Estado foi capaz de ações modernizadoras mesmo se valendo de uma organização autoritária e privatista de mando. Esta interpretação tem sido utilizada por intelectuais contemporâneos como Domingues (2008, 2017), que recusam a caracterização tradicionalista do Brasil em favor da demarcação de seus dilemas "modernos".

3 Gostaríamos de agradecer as sugestões dos pareceristas anônimos de Política $E$ Sociedade, pois foram importantes contribuições para o trabalho. É preciso frisar, contudo, que os argumentos contidos no artigo são de nossa inteira responsabilidade.

4 Sobre a relação de entre público e privado, é importante citar o trabalho de André Botelho (2007, p. 49-50), que faz um importante levantamento de como a questão foi tratada pela sociologia política brasileira: "O baralhamento entre público e privado enquanto ordens sociais e princípios distintos de orientação das condutas como uma marca da cultura política, da sociedade e do Estado formados no Brasil desde a colonização portuguesa constitui uma das construções intelectuais mais tenazes do seu pensamento social. E também uma das principais linhas que, com continuidades e descontinuidades, o liga à produção das ciências sociais posterior à institucionalização, particularmente na vertente voltada para a investigação das bases sociais da vida política nacional, suas raízes rurais e influências duradouras sobre o urbano então emergente".

5 Sobre essa questão, Sell (2007, p. 244) argumenta: "Mas, apesar destas diferenças, elas levaram ao mesmo diagnóstico da realidade brasileira. Quer dizer, neste caso a 'leitura do Brasil' que resultou destas distintas leituras de Weber foi a mesma: a identificação de elementos sociais ou políticos que representam entraves históricos poderosos para a consolidação da modernidade no Brasil”. 
A formulação conceitual de Schwartzman representou a ruptura com as narrativas baseadas na sociologia da dominação weberiana sobre o domínio esencialmente tradicional entre nós ${ }^{6}$. Com o conceito de neopatrimonialismo, portanto, teríamos a possibilidade de demarcarmos os dilemas modernos ao analisarmos a relação problemática em público e privado no Brasil contemporâneo ${ }^{7}$. Para Schwartzman, o país nunca teria sido tradicional, pois foi neopatrimonial desde a sua formação (BRITO, 2015). Certamente, este é um dos pontos mais relevantes do trabalho, pois buscou romper com as interpretaçóes de autores como Raymundo Faoro ${ }^{8}$ (2008), para o qual o Brasil seria essencialmente tradicional. Ao mesmo tempo, é relevante enfocar a busca do autor por uma interpretação teórico-conceitual original para explicar as formaçóes sociais e políticas apartadas do feudalismo. Apesar de apresentarmos uma perspectiva crítica neste artigo, é fundamental demarcar a importância da teorização de Schwartzman. Também é importante apontarmos como Bases do Autoritarismo Brasileiro foi uma obra representativa do contexto de luta contra o regime militar nos anos $1970^{9}$ :

6 Ribeiro (2010) demonstra que Bases do Autoritarismo Brasil representou, de fato, uma ruptura com a narrativa faoriana que absolutizava o atraso brasileiro. Contudo, o autor sustenta que a importância do feudalismo nas obras dos dois intelectuais faz com que a ruptura seja parcial, apesar da narrativa moderna formulada pelo sociólogo mineiro

7 Nesse sentido a interpretação de Jessé Souza (1999) é equivocada, pois o sociólogo limita sensivelmente sua interpretação da obra de Schwartzman ao defender que Bases do Autoritarismo Brasileiro representou apenas uma simples continuação de São Paulo e o Estado Nacional. Como demonstraremos neste artigo, Bases do Autoritarismo Brasileiro foi constituído como uma revisão aprofundada do ponto de vista teórico-conceitual de sua primeira edição, que foi exatamente o livro criticado por Souza como a visão definitiva de Simon Schwartzman sobre o Brasil.

8 De acordo com Brito (2015, p. I 10, grifos meus): "Aqui se materializa a diferença essencial entre Schwartzman e Faoro, como já aludimos. Enquanto o primeiro argumenta que o Brasil nunca foi uma sociedade tradicional, e por isso uso o conceito de neopatrimonialismo, o segundo sustenta que o Brasil foi e continua sendo uma sociedade tradicional, por meio das modernizações, e disso decorre a aplicação da categoria patrimonialismo". Mesmo assim, Brito (2015, p. 149) pondera: "Como dissemos acima, se a teorização de Schwartzman parece avançar em relação à de Faoro no que se refere à caracterização moderna da dominação política no Brasil, esse avanço é frágil, pois não ficam claras quais seriam as suas implicações”. Acreditamos que a fragilidade ocorre também do ponto de vista teórico-conceitual, pois, como demonstraremos, o conceito do sociólogo mineiro está pautado em uma leitura apologética da sociologia de Max Weber.

9 É importante lembramos que a primeira edição do livro, com o título São Paulo e o Estado Nacional, foi publicada em 1975. O conceito de neopatrimonialismo, por sua vez, é formulado em 1982 no livro Bases do Autoritarismo Brasileiro, que repete partes do primeiro livro e acrescenta a parte teórico-conceitual sobre neopatrimonialismo. Por isso, a menção ao contexto de luta contra o regime militar na década de 1970. 
Mais: é possível dizer que Schwartzman “internalizou” as condições de seu contexto na sua reflexão: nela se encontram articulados, por meio do conceito de (neo) patrimonialismo, a incorporação do debate norte-americano sobre o desenvolvimento e a ênfase no papel do Estado na má formação social do país. Talvez por isso o livro seja representativo do período, o que ajuda a fornecer interesse e torna seu estudo uma questão interessante. (BRITO, 2015, p. 106).

Assim como o conceito de patrimonialismo, que somente agora tem recebido um tratamento crítico sobre sua utilização no Brasil (SELL, 2016), o conceito de neopatrimonialismo é empregado para explicar a corrupção e o regime oligárquico de mando existente no país. $\mathrm{O}$ conceito, todavia, é mobilizado por nossos intelectuais de maneira naturalizada - ou seja, sem a devida apreciação crítica nos aspectos epistemológico e teórico-conceitual -, pois é usado como se fosse um termo autoexplicativo.

Carlos Sell (2016) faz uma análise exegética sobre a formulação do conceito de patrimonialismo em Max Weber, a partir de sua versão original, para negar sua validade teórica no caso brasileiro. A leitura do patrimonialismo no Brasil não satisfaz quando demarcamos a dimensão exegética (SELL, 2016). Pretendemos problematizar a utilização da categoria "neopatrimonialismo" ao discutirmos as possibilidades heurísticas outorgadas pelas proposiçóes de Luhmann, de modo a analisar as variaçóes da modernidade política, mais especificamente, as suas variantes "não constitucional" e "autocrática”. Devido à ausência de uma leitura cuidadosa sobre a construção do conceito e do sentido de sua utilização entre nós, temos como objetivo neste artigo analisar criticamente a formulação do termo e sua utilização para compreender a condução do Estado no Brasil contemporâneo.

O tema do patrimonialismo, apesar de weberiano, também merece tratamento a partir da teoria da diferenciação funcional de Niklas Luhmann. A teoria social de Luhmann vem sendo recebida de modo criativo no cenário brasileiro e latino-americano; assim, nossa proposta de utilizá-la como alternativa ao conceito de "neopatrimonialismo" se insere neste esforço coletivo de desenvolvimento e adaptação da teoria para realidades sociopolíticas distintas da Europa. ${ }^{10}$ Isso se justifica porque o conceito de patrimonialismo em

I0 A recente edição da revista Sociologia e Antropologia (vol. 10, n. I) traz um dossiê com alguns dos mais interessantes e proeminentes esforços de recepção crítica da teoria social e política de Luhmann para a análise 
Weber, como ressalta Thomas Schwinn (2001), também está relacionado ao problema da diferenciação da esfera política: patrimonialismo e diferenciação da política são incompatíveis, ainda que possam coexistir no momento de nascimento de estados nacionais. Ao ressaltar que a modernidade política é incompatível com patrimonialismo - ou seja, a política como esfera de valor automizada -, Weber deixa uma fenda de diálogo com a sociologia política de Luhmann, que tenta aprofundar a análise dos problemas resultantes desta autonomização/diferenciação funcional da política.

$\mathrm{O}$ artigo está divido em quatro seçóes. $\mathrm{Na}$ primeira seção, situamos o uso dos conceitos de patrimonialismo e neopatrimonialismo no pensamento social e político brasileiro na linhagem de recepção específica que Weber recebeu no Brasil, orientada para retirar do autor conceitos que pudessem explicar ao "atraso brasileiro", ou seja, nossos problemas de acesso à modernidade. $\mathrm{Na}$ segunda seção, tentaremos demonstrar como o conceito de neopatrimonialismo reproduz os pressupostos sobre a singularidade sociocultural brasileira, sendo incapaz de romper com o discurso sociológico hegemônico sobre a modernidade (TAVOLARO, 2014), o qual constrói descriçóes idealizadas sobre a modernidade central como contraponto comparativo para caracterizar a singularidade da modernidade periférica. $\mathrm{Na}$ terceira seção, discutiremos como o conceito de neopatrimonialismo descreve fenômenos de inclusão política e social a fim de compreender países periféricos como possuidores de uma modernidade singular, na qual a diferenciação funcional entre política e sociedade seria solapada por estruturas específicas deste tipo particular de contexto nacional e regional. $\mathrm{Na}$ quarta seção, discutiremos como a idealização que o conceito de neopatrimonialismo opera da modernidade política dos países centrais o torna inadequado para descrever a complexidade da política moderna, inclusive na periferia. Argumentamos, especialmente, que a oscilação entre formas constitucionais democráticas e anticonstitucionais/autocráticas de estruturação e prática do poder político é um traço da sociedade moderna como um todo, e não uma singularidade nacional ou regional. 


\section{A recepção de Max Weber no Brasil}

A exposição dos objetivos, valores e modos como Weber foi recepcionado no Brasil é fundamental para compreendermos o sentido do conceito de neopatrimonialismo que é conferido pela formulação de Schwartzman. Villas Bôas (2014), cuja preocupação central é analisar os valores que conduziram a recepção de Weber, argumenta que, durante longo período, nossos intelectuais se debruçaram sobre o país com intuito de demarcar suas particularidades para apontar as possibilidades de desenvolvimento, uma vez que o Brasil seria marcado pela perspectiva do descompasso em relação aos países centrais, "modernos" e "desenvolvidos".

Como traço decisivo, foi reproduzida uma interpretação que demarcava a dualidade entre tradição e modernidade11 (VILLAS BÔAS, 2014). Com isso, parte dos sociólogos brasileiros reproduziu uma perspectiva normativa que possuía como elemento central a institucionalizaçáo da sociedade moderna como supostamente existente nos países centrais (VILLAS BÔAS, 2014).

Segundo Werneck Vianna (1999), o Weber recepcionado no Brasil não fora aquele das patologias da modernidade, mas sim do acesso ao moderno. O autor propõe duas formas de recepção de Weber no Brasil a partir de sua sociologia da dominação e da consequente perspectiva do "atraso": o "patrimonialismo estatal”, que seria oriundo da herança ibérica, e o "patrimonialismo societal", oriundo das relações de produção no mundo agrário (WERNECK VIANNA, 1999).

Na ponta da recepção de Weber, denominada por Werneck Vianna de "patrimonialismo de Estado", o Brasil havia herdado uma cultura privatista com a transferência do Estado português para o país, uma vez que o Estado antecede aos grupos de interesse, sendo o grande responsável por mazelas como a desigualdade social (WERNECK VIANNA, 1999). Como consequência, nossos males seriam provenientes da colonização ibérica. Nesse

II De acordo com Dias ( 1974, p. 49), o primeiro trabalho sobre o sociólogo alemão no Brasil foi elaborado por Emílio Willens, que publicou o artigo Patrimonialismo e Administração na Revista de Administração Pública, em 1945. A partir da leitura pioneira de Willens, foram realizados outros trabalhos por intelectuais como Guerreiro Ramos, Costa Pinto e Florestan Fernandes, cujos temas giravam em torno da burocracia como tipo ideal, modalidades de poder e as dimensões e tipos de estratificação social (DIAS, 1974, p. 49). As primeiras leituras de Weber no Brasil, contudo, não foram realizadas em alemão, mas sim através das traduções em espanhol e inglês. 
sentido, essa interpretação teria como fim político-normativo a reforma do Estado, a qual poderia abri-lo à diversidade dos interesses existentes na sociedade civil. Dessa forma, o sistema de representação seria imposto, bem como os interesses seriam libertos de qualquer razão tutelar (WERNECK VIANNA, 1999). Com a concessão de liberdade à diversidade de interesses na sociedade haveria a constituição de uma dinâmica positiva, que teria como ponto principal produzir maior igualdade social (WERNECK VIANNA, 1999). Além destas características, esta ponta da recepçáo de Weber ainda seria a versão hegemônica na academia e na opinião pública brasileira (WERNECK VIANNA, 1999). Esta versão que nós sumariamos rapidamente tem como ponto fundamental a política como foco analítico, pois o Estado seria o grande entrave à consolidaçáo da modernidade no Brasil (SELL, 2007).

Já a outra variante da recepção de Weber tem na sociologia seu suporte. Esta interpretaçáo afirma que nosso patrimonialismo é fruto das relaçóes de produção no mundo agrário, sendo o patrimonialismo brasileiro societal. A recepção de Weber que aponta o nosso patrimonialismo como oriundo da herança ibérica produz uma visão do Estado como uma unidade per se, ou seja, gerido a partir de uma lógica própria em sua relação com a sociedade. Já para a recepçáo de Weber que enfoca o patrimonialismo societal, o Estado é considerado como instrumento da dominação de classes. Além disso, o Estado não se caracteriza como um Estado português prolongado. Para essa ponta da recepção de Weber houve uma combinação ambígua entre a ordem racional legal advinda do Estado e a patrimonial oriunda da sociedade civil, que formaram, desde a independência, uma relação de compromisso. A ruptura não deveria ser feita ao nível do Estado, mas sim no âmbito das relaçóes sociais de padrão patrimonial (WERNECK VIANNA, 1999). Além disso, a exposição nos auxilia a demonstrar a centralidade do conceito para explicar os principais dilemas políticos brasileiros.

Carlos Sell (2016), por sua vez, argumenta que as interpretaçóes brasileiras ignoram que o tema do patrimonialismo em Weber é embasado em dois modelos separados pela Primeira Guerra Mundial. Nos primeiros escritos de Weber, o patrimonialismo seria uma derivação do patriarcalismo (SELL, 2016). Na produção do pós-guerra, Weber defende que dominação 
patrimonial possui uma relação de descontinuidade em relação à dominação patriarcal (SELL, 2016) No caso brasileiro, existe a mistura dos dois modelos sem a devida atenção às descontinuidades (SELL, 2016). Em virtude da não atenção às mudanças internas nas formulaçóes de Weber em sua sociologia da dominação, as leituras brasileiras perdem validade teórica quando relacionadas à formulação original dos escritos de Weber (SELL, 2016). Tendo em vista a demarcação dessa importante inconsistência das leituras baseadas na sociologia política weberiana, Sell (2016) propóe uma tipologia sobre nossos autores que nos parece mais consistente que a formulação de Werneck Vianna (1999) sobre o "patrimonialismo de Estado" e o "patrimonialismo societal", uma vez que esta última não oferece a possibilidade de observarmos os conteúdos diferentes que existem nas formulações:

Portanto, em adição a essa dicotomia, gostaria de sugerir uma nova tipologia entre, de um lado (e afim ao modelo doméstico do Weber da primeira fase), a linhagem "societário-patriarcal" que se define pela tese da corrosão do caráter público do Estado pela lógica personalista presente nas relações doméstico-privadas (HOLANDA, 1936). De outro lado, por sua vez (e em afinidade com o modelo organizacional do Weber tardio), temos também a linhagem "liberal-institucionalista", na qual o conceito de patrimonialismo é mobilizado para identificar as barreiras históricas que bloqueiam a institucionalização do liberalismo político-econômico no Brasil (FAORO, 1975). Nesse modelo o patrimonialismo é definido, em última instância, como estatismo. (SELL, 2016, p. 21-22).

Na próxima seção tentaremos demonstrar como o conceito de neopatrimonialismo reproduz os pressupostos sobre a singularidade sociocultural brasileira, sendo incapaz de romper com o discurso sociológico hegemônico sobre a modernidade que constrói descriçóes idealizadas sobre a modernidade central como contraponto comparativo para caracterizar a (suposta) singularidade da modernidade periférica.

\section{Neopatrimonialismo e a singularidade brasileira}

A utilização dos conceitos oriundos da sociologia política weberiana, como patrimonialismo e neopatrimonialismo, tem como pano de fundo demarcar o "atraso" e a singularidade que supostamente seriam marcas decisivas do Brasil contemporâneo. Tavolaro (2014) argumenta que a ideia em torno da existência de uma singularidade no Brasil tornou-se o 
elemento mais forte em nosso pensamento social e político porque diversos autores e correntes, cada qual a seu modo, reproduziram esta tese que foi crucial para formatar a autoimagem construída e consolidada entre nós.

A partir da demarcação do discurso sociológico dominante sobre a modernidade, Tavolaro (2014) delimita a profunda limitaçáo que existe nas interpretaçóes que defendem a existência de uma singularidade irredutível do Brasil, que teria uma diferença essencial em relação aos países centrais. Essa profunda limitação ocorre porque as comparações realizadas por nossas principais interpretações não foram fundamentadas empiricamente.

Nossa singularidade foi constituída através deste discurso sociológico sobre a modernidade, definido pelos seguintes aspectos: diferenciação/ complexificação social; secularização; separação entre os domínios público e privado; subjetividade autocentrada e divórcio entre sociedade e natureza (TAVOLARO, 2014). Como as características acima citadas funcionam como fatores distintivos da chamada "modernidade originária", nossa singularidade é demarcada, precisamente, pela ausência desses elementos.

A partir da discussão sobre a singularidade brasileira, defenderemos que Schwartzman se baseia no discurso sociológico sobre a modernidade para formular o conceito de neopatrimonialismo, que demarca a modernidade negativa e inautêntica que teria sido formada em decorrência da herança ibérica. Conjuntamente, demonstraremos como o conceito formulado pelo sociólogo mineiro reproduz pressupostos presentes na teoria da modernização, que foi fundamental para disseminar o discurso sociológico sobre a modernidade responsável por nos deixar em posição de permanente incompletude e inferioridade frente aos países centrais.

Antes de analisarmos o conceito de neopatrimonialismo; porém, é necessário apontar como o sociólogo mineiro chegou à formulação no livro supracitado, pois até Bases do Autoritarismo Brasileiro, Schwartzman (1975) utilizava o conceito de patrimonialismo para caracterizar o autoritarismo político e a condução privatista do Estado brasileiro. $\mathrm{O}$ autor defendia que, além do domínio patrimonial, havia um desenvolvimento de base contratual radicado no Estado de São Paulo, que seria capaz de vencer o atraso caso fosse generalizado para o restante do país. Sua obra possuía uma 
clara inspiração em Faoro (WERNECK VIANNA, 2009). Neste sentido, Schwartzman pode ser visto como o continuador mais eminente da obra do jurista gaúcho (SOUZA, 1999).

Em São Paulo e o Estado Nacional, Schwartzman (1975) tem como objetivo central defender que a marginalização política do Estado de São Paulo foi crucial para a não constituição de uma ordem moderna e representativa no Brasil. Nesse momento, o patrimonialismo possuía um caráter eminentemente tradicional, ainda muito próximo de Faoro, a quem Schwartzman cita sem apropriação crítica. Em virtude disso, o autor interpreta o país como plenamente atrasado devido ao domínio do patrimonialismo, pois sua interpretação possui uma forte inspiração na obra de Faoro (WERNECK VIANNA, 2009).

Schwartzman, todavia, revê as suas posições sobre o patrimonialismo defendidas em São Paulo e o Estado Nacional, ao publicar, em 1982, Bases do Autoritarismo Brasileiro - obra na qual a absolutização do atraso é relativizada. Em Bases do Autoritarismo Brasileiro, Schwartzman propóe uma revisão teórica do patrimonialismo presente em seu livro anterior, fazendo com que o conceito de neopatrimonialismo funcionasse como um demarcador da singularidade das sociedades que se formaram do patrimonialismo como o Brasil moderno. Contudo, demonstraremos que o conceito de neopatrimonialismo não revê os pressupostos presentes no antigo conceito de patrimonialismo, especialmente em relação à diferenciação do sistema político e aos problemas de inclusão e exclusão daí decorrentes.

Bases do Autoritarismo Brasileiro teria um caráter “[...] mais declaradamente teórico e conceitual, que pretende ser também mais abrangente e fundamentado" (SCHWARTZMAN, 1888, p. 9). Por meio da modificação trazida pelo conceito de neopatrimonialismo, o elemento tradicional absolutizado, como muito bem identificou Souza (1999) em sua interpretação de Sáo Paulo e o Estado Nacional, seria relativizado em Bases do Autoritarismo Brasileiro. Como mostra dessa nova postura, Schwartzman (1988) critica duramente Faoro por dar ao patrimonialismo um caráter absoluto e imutável no tempo, além do fato de não ter visto o caráter efetivamente modernizador deste em vários momentos da história brasileira.

Para esta mudança, responsável pela construção do conceito de neopatrimonialismo, Schwartzman foi bastante influenciado pela leitura das 
obras de José Murilo de Carvalho (2008), que analisou detidamente a elite imperial brasileira, e de Antonio Paim (1998), que produziu uma interpretação sobre o Estado patrimonial brasileiro e sua ação modernizadora.

Da obra de Carvalho (2008), Schwartzman retira a caracterização da burocracia brasileira. $\mathrm{O}$ estamento teria como base fundamental a honra. Carvalho (2008) afirma que a burocracia brasileira era dividida em vários setores. Além disso, Carvalho advoga que a constituição da burocracia provinha da socialização e do treinamento, e não do privilégio (CARVALHO, 2008).

Neste sentido, Schwartzman (1988, p. 60) argumenta que: "Esta ausência de 'honra social por mérito próprio' é o que torna inadequada a expressáo 'estamento burocrático', utilizada por Raymundo Faoro para sua análise do Estado brasileiro". Já de Antonio Paim (1998) o autor retira a tese de que o patrimonialismo teve um caráter efetivamente modernizador no Brasil.

As publicaçóes de Carvalho e Paim fizeram com que Schwartzman também se afastasse de Faoro, pois o caráter de absolutização do atraso defendido pelo jurista gaúcho funcionava, agora, como um dos fatores limitadores de sua interpretação. Por isso, caracterizar a interpretação feita por Schwartzman como dominada pelo elemento tradicional mostra-se um equívoco (SCHWARTZMAN, 2003).

A partir da diferenciação entre patrimonialismo e feudalismo, o sociólogo mineiro afirma que os Estados modernos nascidos à margem da revoluçáo burguesa seriam caracterizados como neopatrimoniais. Estes Estados seriam capazes de se modernizar e racionalizar sua burocracia, “[...] mas sua base de poder e seus sistemas políticos serão, necessariamente, bem diferentes dos das democracias ocidentais. E eles são, naturalmente, a maioria dos países não ocidentais de hoje" (SCHWARTZMAN, 1988, p. 67) Para Schwartzman (1988), a teoria weberiana seria responsável por fornecer um instrumental conceitual para demonstrar que o Estado brasileiro possui como característica central sua dimensão neopatrimonial.

Como veremos à frente, Schwartzman constrói dois caminhos para se chegar à modernidade, um positivo e autêntico; outro negativo e inautêntico - este último característico do caso brasileiro. Para defender a diferença existente entre os países surgidos do feudalismo e os nascidos do 
patrimonialismo, o sociólogo mineiro afirma que a diferença existente entre as democracias ocidentais e a sociedade brasileira é que está última está imersa em um processo interminável de instabilidade (SCHWARTZMAN, 1988). Havia, portanto, a necessidade de examinar a natureza distinta dos Estados formados pelas vias feudal e patrimonial, além de analisar as relaçóes destes com a sociedade (SCHWARTZMAN, 1988).

Schwartzman (1988) advoga que as sociedades que passaram pela experiência feudal constituíram um sistema descentralizado com grande desenvolvimento econômico neste século. Todavia: "Sua ausência e o predomínio no passado de um Estado burocratizado e excessivamente grande é que parece terem sido determinantes do atraso relativo de muitos países no presente" (SCHWARTZMAN, 1988, p. 58).

Ainda como maneira de diferenciar os Estados formados do feudalismo e do patrimonialismo, o autor analisa um dos fenômenos mais importantes do Estado moderno: o corporativismo. De acordo com Schwartzman (1988, p. 67), essa polarização dicotômica entre feudalismo e patrimonialismo teria gerado duas formas de corporativismo: um de caráter autoritário resultante do patrimonialismo, e outra "[...] resultante da reorganização de setores importantes da sociedade, após os efeitos devastadores da revolução burguesa”. Neste caso, a sociedade se organiza a partir de situaçôes de mercado, estabelecendo limites e parâmetros definidos à ação do Estado (SCHWARTZMAN, 1988). No corporativismo nascido do feudalismo teríamos uma sociedade organizada de forma contratual, ou seja, a partir de situaçóes de mercado, estabelecendo limites e parâmetros de forma clara à ação do Estado (SCHWARTZMAN, 1988, p. 67).

No caso do corporativismo nascido do patrimonialismo teríamos a constituição de um Estado forte, caracterizado pela existência de componentes neopatrimoniais bastante fortes. Este seria "capaz de impor sua vontade e seus ordenamentos à sociedade civil” (SCHWARTZMAN, 1988, p. 67). Isto faria com que os Estados modernos nascidos à margem da revolução burguesa fossem caracterizados como neopatrimoniais ( $\mathrm{SCH}$ WARTZMAN, 1988).

Nesse sentido, Schwartzman (1988, p. 59) afirma que o patrimonialismo moderno, ou neopatrimonialismo, não seria o receptáculo de 
estruturas tradicionais nas sociedades contemporâneas, “[...] mas uma forma bastante atual de dominação política por um 'estrato social' sem propriedades e que não tem honra social por mérito próprio, ou seja, pela burocracia e a chamada classe política”.

Para a construção do conceito de neopatrimonialismo, Schwartzman (1988) parte da utilização feita por Shmuel Eisenstadt (1973) que a usou para caracterizar os Estados modernos que se constituíram fora do Ocidente. Esta utilização tinha como característica a sobrevivência de formas tradicionais, que foi rejeitada por Schwartzman em sua utilização do conceito:

A linha de continuidade que Weber estabelece entre dominação patrimonial tradicional e dominação burocrática (que leva a falar, muitas vezes, em "patrimonialismo burocrático") deve ser vista em contraste com a continuidade que parece existir entre feudalismo e dominação racional-legal, que surge historicamente associada à emergência do capitalismo. (SCHWARTZMAN, 1988, p. 59-60).

Esta diferenciação entre feudalismo e patrimonialismo fez com que estes gerassem a dominação racional-legal e o neopatrimonialismo, respectivamente. Dessa forma, feudalismo e patrimonialismo teriam um aspecto "tradicional", enquanto dominação racional-legal e neopatrimonialismo seriam caracterizados pelo seu aspecto "moderno" (SCHWARTZMAN, 1988).

Schwartzman (1988) constitui sua interpretação do Brasil a partir da análise dividida em dois níveis: o estrutural e o político. A abordagem estrutural caracteriza-se pela existência de uma relação entre o desenvolvimento histórico surgido da Europa feudal que foi responsável por conduzir às sociedades capitalistas modernas, ocidentais e desenvolvidas, e outra que ligaria as sociedades patrimonialistas tradicionais às sociedades contemporâneas subdesenvolvidas (SCHWARTZMAN, 1988).

O nível político seria caracterizado pelo regime de cooptação política. A junção entre os níveis estrutural e político legaria para as relaçóes políticas no Brasil o "patrimonialismo político". Com tal constituição histórica recebemos como herança de Portugal seu modelo burocrático e patrimonial. Este poder, originário da Casa de Avis, chegou primeiro ao solo brasileiro com o Governo Geral em 1548, sendo reforçado com a chegada da família real em 1808. Devido a essa herança, o Brasil possuía o 
domínio da cooptação política. Este domínio fez com que a política girasse em torno do Estado e de sua representação (SCHWARTZMAN, 1988, p. 67). Schwartzman se opóe à caracterização da cooptação política como um fenômeno apenas existente na América Latina, possivelmente como forma de refutar um essencialismo culturalista. Partindo de Reinhard Bendix (1956), Schwartzman afirma que tal fenômeno também ocorreu em países como a Rússia Czarista e a Alemanha Oriental.

O sociólogo mineiro procura refutar a caracterização da sociedade brasileira como pré-moderna, ou seja, dominada plenamente pelo elemento tradicional. Para o autor, a modernidade possuiria dois caminhos para ser instituída. Um possui um caráter positivo e autêntico, que tem como fase necessária a passagem pelo feudalismo. $\mathrm{O}$ outro caminho tem como característica o caráter negativo e inautêntico, ou seja, seria responsável pelo surgimento de uma modernidade deformada em virtude de sua constituição a partir de um passado patrimonialista.

Schwartzman (1988) faz uma leitura particular da obra de Max Weber, o que o leva a criar o seguinte quadro evolucionista para compreender o processo de mudança social para formação dos dois tipos de modernidade que caracterizariam os países centrais e o Brasil:

Quadro I - Tipologia de dominação política em Weber

\begin{tabular}{|c|c|c|}
\hline Relação de poder & Absoluta & Contratual \\
\hline Tradicional & Patrimonialismo & Feudalismo \\
\hline Moderno & $\begin{array}{c}\text { Patrimonialismo burocrático } \\
\text { (neopatrimonialismo) }\end{array}$ & Dominação racional legal \\
\hline
\end{tabular}

Fonte: Schwartzman (1988).

Para Schwartzman, existiria uma evolução teleológica bifurcada em direção a dois tipos distintos de modernidade. E essa evolução teleológica refere-se a países e regióes específicas, sendo, portanto, também prisioneira do "nacionalismo" e do "regionalismo" metodológico. Apesar de Schwartzman afirmar que sua proposição de neopatrimonialismo está pautada pela teoria weberiana, sua construção teórica não é, de fato, weberiana, uma vez 
que "nada mais estranho a Weber do que uma sequência de tipo teleológico" (SELL, 2016, p. 6). Isto ocorre porque a teoria weberiana possui um caráter primordialmente sociológico-tipológico e não histórico-evolutivo como presente na interpretação de Schwartzman, pois em suas investigaçôes histórico-comparadas, Weber utilizava os tipos mistos (SELL, 2016, p. 20). Nesse sentido, Sell (2013, p. 11) argumenta que: "A racionalidade em Weber possui, antes de tudo, um estatuto metodológico e não é uma propriedade ontológica do mundo". Ainda de acordo com Sell (2016, p. 20), “[...] tais análises ignoram que a categoria patrimonialismo não é utilizada nas análises histórico-causais weberianas em contraste com a burocracia, nem com o feudalismo". Logo, Weber não tinha como interesse demarcar a singularidade e consequente normalidade da formação europeia (SELL, 2016) como está presente na formulação criada pelo sociólogo mineiro para sustentar a validade do conceito de neopatrimonialismo. Para Weber, o Ocidente representava, na verdade, um grande "desvio histórico" (SELL, 2016, p. 20). Assim, o eurocentrismo presente na formulação de Schwartzman não deriva da formulação original de Weber.

Souza (1999) defende que Weber estrutura sua teoria por um evolucionismo formal ou neoevolucionismo. A sociologia weberiana não se enquadraria, por exemplo, no evolucionismo material, como o existente em Schwartzman que coloca como caminho necessário para o surgimento da modernidade a passagem pelo feudalismo, sendo, neste aspecto, muito próxima da concepção sistêmica de Luhmann sobre a evolução sociocultural, marcada por contingência e não por teleologia. Por isso, sugerimos, nas próximas seçóes, utilizar a sociologia de Luhmann, especialmente sua sociologia política, para propor conceitos alternativos ao de patrimonialismo ou neopatrimonialismo a fim de descrever fenômenos de exclusão política.

Portanto, não existiriam etapas necessárias ao desenvolvimento com validade universal como postula a interpretação de Schwartzman. O neoevolucionismo weberiano, ao negar a existência de etapas necessária para a mudança social acreditaria na existência de estágios de desenvolvimento com validade universal (SOUZA, 1999). Assim, os estágios de desenvolvimento hierarquizáveis e com pretensóes de validade universal se concentrariam nos aspectos moral e cognitivo (SOUZA, 1999). Portanto, a teoria de Schwartzman não possui nada de efetivamente weberiano, pois autor reproduz uma leitura apologética de Max Weber construída por Talcott 
Parsons. A interpretação de Schwartzman reproduz o mesmo formalismo existente na formulação parsoniana, que deixa de lado a contingência histórica como dimensão analítica (DOMINGUES, 2001, p. 86). A proposição de Schwartzman é pautada por um evolucionismo material que singulariza sua proposição e, ao mesmo tempo, o liga à "teoria da modernização" devido à idealização sociológica presente em sua formulação:

Na leitura da teoria da modernização, Weber legitima a tese de que as sociedades são escalonadas segundo critérios de generalização crescente de valores (individualismo, racionalidade etc.) e instituições autônomas (mercado, Estado, Direito formal, ciência etc.), cuja dinâmica obedece a uma direção universal e unívoca que vai do tradicional ao moderno. (SELL, 2013, p. 297).

A teoria weberiana, portanto, não demarca a racionalidade ocidental e moderna como um télos imanente em direção a um futuro previsível (SELL, 2013). Como afirma Richard Morse (1989), Simon Schwartzman postula uma visão linear da história. A tipologia criada por Schwartzman o afasta de Weber e o aproxima da interpretação liberal apologética da teoria da modernização, com todas as suas carências epistemológicas e teórico-conceituais presentes.

O sociólogo mineiro constrói uma perspectiva formalista e a-histórica para analisar a mudança social, uma vez que a contingência histórica deixa de ser elemento significativo na interpretação como ocorre com a teoria da modernização. Além disso, Schwartzman segue a teoria da modernizaçáo ao reproduzir seletivamente o diagnóstico de Max Weber, pois retira dele a ambivalência. Dessa forma, a modernidade seria estruturada como uma sociedade meritocrática na qual os padróes fixos de desigualdade seriam banidos (DOMINGUES, 2001). Ao retirar a ambivalência do diagnóstico weberiano, Schwartzman (1988) reproduz o imaginário da modernidade (DOMINGUES, 2011).

O autor, portanto, repete a leitura unilateral e apologética da teoria weberiana, responsável por construir uma visão estritamente positiva e, portanto, idealizada da modernidade que foi utilizada como parâmetro para interpretar o caráter negativo e inautêntico da modernidade brasileira. Esta visão linear e evolucionista faz com que o autor postule que a modernidade se constitui a partir da continuidade com o elemento tradicional, como nas relaçóes necessárias entre feudalismo e capitalismo, e patrimonialismo e neopatrimonialismo, como ocorre com a teoria da modernização. 
Se o autor possui o mérito de rever suas posiçóes contidas em São Paulo e o Estado Nacional, que absolutizavam o "atraso" brasileiro, constrói, no entanto, uma via alternativa muito frágil e limitada teoricamente para interpretar o Brasil moderno, visto que náo se sustenta em seus pressupostos fundamentais. Em virtude destas limitaçóes, questionamos a validade do conceito de neopatrimonialismo. Na próxima seção, discutiremos como o conceito de neopatrimonialismo descreve fenômenos de inclusão política e social a fim de compreender países periféricos como tendo uma modernidade singular, na qual a diferenciaçáo funcional entre política e sociedade seria solapada por estruturas específicas deste tipo de contexto nacional e regional.

\section{Neopatrimonialismo, inclusão e diferenciação funcional}

Nesta seção buscaremos averiguar em que medida o conceito de neopatrimonialismo pode ser entendido como uma semântica que articula problemas de inclusão e exclusão relacionados à diferenciação do sistema político entre nós. $\mathrm{O}$ estudo das relaçôes entre Estado e sociedade articula uma questão-chave da vida social e política na modernidade: a diferenciação entre o sistema político e seu ambiente social circundante (LUHMANN, 2002; BOURDIEU, 2011, 2014). A diferenciação do sistema político, realizada com a formação dos Estados nacionais e a dissolução das hierarquias estamentais enquanto critério autoevidente de dominação está constitutivamente ligada à norma da inclusão universal dos indivíduos nos processos de formação da vontade e das decisóes políticas 12 .

Em países como o Brasil, nos quais, apesar da universalização formal do acesso ao voto e aos cargos eletivos, persiste exclusão estrutural de

12 As análises de Luhmann ( 198 Ia; 198 Ib; 2002; 20 I0) sobre a diferenciação do sistema político e as relações entre estado e sociedade, desenvolvidas e aperfeiçoadas por outros autores da teoria dos sistemas (STICHWEH, 2016), constituem uma rica perspectiva de sociologia política que dialoga direta e indiretamente com diferentes correntes da teoria e da ciência política e aborda os mais variados temas que se ramificam a partir do eixo diferenciação e acoplamento entre política e sociedade. Entre os temas abordados estão as diferentes formas de inclusão política (participação, representação etc.), os diferentes circuitos de poder (formal e informal), o papel das organizações de interesse, a legitimação procedimental da política moderna, os desafios do estado de bem-estar social para a relação entre política, direito e sociedade, e evolução das semânticas políticas em correlação com a evolução das estruturas do sistema político e da sociedade etc. Neste artigo buscamos explorar a distinção entre poder formal e informal, assim como a bifurcação correlata entre poder constitucional e poder não constitucional, parar fornecer uma alternativa às análises baseadas nos conceitos de patrimonialismo e neopatrimonialismo. 
parcelas significativas da população dos processos decisórios, a relação entre exclusão social e exclusão política constitui um dos tópicos principais da reflexão acadêmica sobre o funcionamento da política.

O problema central, se pudermos reformulá-lo em termos sistêmicos, é o de articular a ideia de diferenciação funcional da política, que o conceito de neopatrimonialismo pressupóe de modo idealizado no centro e nega na periferia, com a constatação de influências recíprocas entre exclusão social e exclusão política em massa, que é, afinal, o fenômeno que o conceito aqui analisado busca explicar com seu foco no fechamento das posiçóes de poder político a determinados "grupos estamentais" da sociedade.

A diferenciação funcional do sistema político deriva diretamente da diferenciação de papéis sociais complementares vinculados ao exercício do poder: a diferença entre os papéis de governante e governado (SCHNEIDER, 2010). Somente quando estes papéis se distinguem de outros papéis sociais - sobretudo dos papéis hierárquicos da sociedade estamental -, reforçando a centralização e monopolização do uso legítimo da violência física enquanto garantia material desta distinção binária especificamente política entre quem governa e quem não governa, é que se pode, segundo Niklas Luhmann (1989), falar da política como um subsistema diferenciado do restante da sociedade. O subsistema político (LUHMANN, 2002, p. 243) não deve ser confundido com o Estado; este é apenas a organização central das unidades "segmentares" do subsistema (os territórios nacionais), isto é, a organização que concentra a responsabilidade de produzir decisóes coletivamente vinculantes dentro deste território.

Embora os critérios de inclusão e exclusão específicos da política guardem relações com fatores exteriores ao campo político, a diferenciação do sistema político implica necessariamente a dissolução da hierarquia estamental enquanto parâmetro autoevidente de dominação. Em lugar da hierarquia de honra e status entre famílias, entra a organização política como instância principal que regula o acesso ao poder.

Enquanto modelo genuinamente moderno de organização política, o Estado nacional vincula-se de modo perene à obrigação de atender aos interesses e assegurar o bem comum das "comunidades imaginadas" (ANDERSON, 2006), invocadas como fundamento legitimador da organização 
estatal. Ainda que este modelo tenha, na Europa, se desenvolvido no final do século XVIII, é somente a partir da segunda metade do século XIX (BAYLY, 2004; GOSWAMI, 2002; HILL, 2008) que ele assume seu potencial universalizador, para o que foi imprescindível o processo global de mútua observação e marcação de fronteiras entre estados e movimentos nacionalistas. O que Luhmann (2002, 224-225) chama de "diferenciação segmentar do sistema político mundial" é produto de um campo global de comparaçóes, no qual os estados em formação, além do intercâmbio direto de mercadorias e ideias, também estabelecem entre si relaçóes de imitação e distinção, conflito e cooperação.

Como Souza (2003) ressalta, o conceito de patrimonialismo não é apenas um conceito da ciência. Tornou-se uma categoria semântica que informa a autocompreensão política do Brasil. Desdobrando esta ideia, gostaríamos também de abordar o conceito de neopatrimonialismo enquanto elemento semântico relacionado aos problemas derivados da diferenciação do sistema político, sobretudo aos problemas envolvendo a relação entre exclusão social e exclusão política. Ao ser utilizado na autocompreensão política do Brasil o conceito de neopatrimonialismo passa ter uma relevância especificamente política, e aí interessa averiguar se e como o desenvolvimento do conceito pode ser interpretado como "resposta semântica" aos "problemas práticos" que dificultam a democratizaçáo efetiva da atividade política, ou seja, aos problemas de exclusão política e suas relações com a exclusão social. Do ponto de vista científico, porém, o que interessa, como buscaremos discutir mais a frente, é se sua relevância política é acompanhada de aplicabilidade enquanto ferramenta de sociologia política comparada. Nosso argumento é que o viés idealizador da modernidade central, com os pressupostos de diferenciação funcional e neutralização do poder social pela universalização da inclusão política, depóe decisivamente contra sua aplicabilidade.

A diferenciação do sistema político é acompanhada pela formação de semânticas que buscam refletir sobre este processo (LUHMANN, 1997). Entre estas semânticas encontram-se tanto "saberes práticos," que orientam a ação social no sistema diferenciado a partir da condensação cultural de experiências, quanto "teorias de reflexão" que se ocupam de problemas derivados da autonomização do sistema, entre eles a busca por mais autonomia e a reflexão sobre os critérios de inclusão e exclusão (LUHMANN, 1997). 
$\mathrm{Na}$ condição de semânticas envolvidas com a observação e a descrição da atividade política, as "teorias de reflexão" sobre a política compartilham com os "saberes práticos" o fato de se ocuparem dos mesmos problemas derivados da diferenciação do sistema político. Ambas são "respostas" às mesmas questóes e problemas reais que se impóem a todos envolvidos com a política, independentemente da intenção e do sentido subjetivo dos atores e autores. Como já sugere a diferenciação entre "saberes práticos" e "teorias de reflexão", as semânticas do sistema político são múltiplas e concorrentes, refletindo, quase sempre, as divisóes e posiçôes produzidas pela atividade política (SCHNEIDER, 2010,). Embora Luhmann, em seus estudos sobre a relação entre "estrutura" e "semântica", tenha se concentrado exclusivamente na sucessão dos tipos de autodescriçóes como fenômeno correlato da crescente diferenciação deste subsistema funcional, é plenamente possível - além de necessário -, como ressalta Schneider (2010, p. 213), relacionar autodescriçóes, que coexistem e divergem no mesmo período de tempo, às divisóes e posiçóes estruturais dentro do sistema.

Após a centralização bem-sucedida do controle do uso legítimo da força e do poder, o problema fundamental a ser enfrentado pelas autodescriçóes da atividade política não é mais o de conceber uma "razão de estado" como solução para o paradoxo moral do "príncipe" que, para alcançar o fim moralmente justificado de assegurar a "ordem, a paz e a justiça”, precisa agir de forma moralmente reprovável, assassinando ou deportando potenciais usurpadores do poder, por exemplo. Uma vez assegurada a diferença entre governante e náo governante por meio da concentração do poder e da violência, o problema deixa de ser esta necessidade de afirmar a autonomia das exigências funcionais da atividade política perante as exigências da moral (SCHNEIDER, 2010); em seu lugar, surge o problema do controle do uso arbitrário do poder. $\mathrm{O}$ exercício do poder, uma vez que não pode mais estar baseado no "cheque em branco" constituído pela fórmula da "razão de estado", vai então precisar ser legitimado pela observação dos direitos do cidadão e do sistema de "freios e contrapesos"/divisão de poderes - a passagem da monarquia absolutista para o Estado constitucional.

É precisamente este processo de "constitucionalização do poder" (NEVES, 2008, p. 481) que resulta na formação de direitos políticos igualitários - a serem exercidos segundo procedimentos eleitorais juridicamente 
controlados - como expressão da noção de soberania popular, concebida como fonte última de legitimação do poder. Na medida em que o acesso e o exercício do poder são regulados por procedimentos jurídicos destinados a garantir tanto a expressão da vontade popular como o uso constitucional do poder, espera-se neutralizar a influência direta do poder social sobre o poder político, assim como o uso arbitrário deste a fim de obter vantagens e corromper o funcionamento de outras esferas sociais - como a esfera privada, a econômica, os meios de comunicação etc. Ou seja, a constitucionalização do poder deve assegurar o acesso de todos ao poder político, e, ao mesmo tempo, cuidar para que ele náo seja exercido arbitrariamente sobre outras esferas da vida social e individual, garantindo, assim, a diferenciação entre política e sociedade. Nesse contexto, as "teorias de reflexão" vão se ocupar primariamente dos problemas relativos à (insuficiente) universalização dos direitos do cidadáo e ao controle do uso arbitrário do poder. Como sintetiza Luhmann (1997, p. 968): “a teoria política torna-se teoria do Estado constitucional".

No entanto, o potencial da sociologia política de Luhmann, inclusive enquanto alternativa ao conceito de "neopatrimonialismo", resulta dos elementos que permitem superar os marcos de uma teoria do "Estado constitucional". Isto exige distanciamento da recepçáo de sua teoria que reproduz a dicotomia caricatural entre uma modernidade política idealizada nos países centrais, marcada pela completude da diferenciação entre as esferas e pela plena constitucionalização e democratização do poder, e uma periferia de regiôes e países definidos pela ausência ou pela incompletude destas características (DUTRA, 2016). O próprio Luhmann nunca logrou se distanciar suficientemente da associação entre modernidade política, democracia constitucional e diferenciação funcional nos países do Atlântico Norte. Em suas referências empíricas sobre a política moderna, predomina, implícita ou explicitamente, a associaçáo entre modernidade política e as experiências sociopolíticas da Europa e da América do Norte. Democracia constitucional e diferenciação funcional da política não são suficientemente separadas em termos conceituais. Esta associação:

Conduz Luhmann a não fazer nenhuma consideração substancial sobre regimes políticos diferentes da democracia liberal representativa, que serve de modelo para observar o sis- 
tema político da sociedade global. Este estreitamento da diversidade de regimes políticos a nível mundial cobra o preço da ignorância sobre como realmente funciona a política nas diferentes regiões do globo. (SAAVEDRA, 2020, p. 109).

Assim, para Luhmann, a configuração política propriamente moderna decorre de evolução da democracia liberal representativa para a constituição dos Estados de bem-estar social que definem a paisagem política dos países do Atlântico Norte no pós-Segunda Guerra Mundial. Na demarcação dos eventos históricos que concretizam o desenvolvimento político moderno, o constitucionalismo liberal que normaliza e formaliza a rivalidade em torno das posições de comando político, através de disjunção binária entre governo e oposição (LUHMANN, 1990), é tratado como caminho sem alternativa para o desenvolvimento dos Estados de bem-estar social com sua dinâmica de amplificação recíproca de inclusão política e social por meio dos direitos fundamentais de cidadania.

Sua concepção de diferenciação funcional se descolou, no final de sua vida e obra, apenas parcialmente de um discurso hegemônico e eurocêntrico sobre a modernidade em geral e a política em particular. Sua teoria da modernidade social e política ainda precisa ser corrigida em seu viés eurocêntrico. Para oferecer uma alternativa ao conceito de "neopatrimonialismo", precisamos de um diálogo entre teoria social e teoria política capaz de superar a concepção eurocêntrica da diferenciação entre as esferas sociais (DUTRA, 2020) e a associação reducionista entre modernidade política e as democracias constitucionais do Atlântico Norte. Precisamos de uma teoria da diferenciação da sociedade que seja capaz de considerar fenômenos de poder autoritário e não constitucional observáveis no Brasil como parte da variedade das formas estruturais e institucionais da modernidade política, sem que suas contradiçôes e incompletudes sejam atribuídas a trajetórias nacionais singulares.

Enquanto "teoria do Estado constitucional", a teoria política perde de vista a dimensão não constitucional da política. Embora Luhmann não tenha se distanciado suficientemente da associação entre modernidade política e as democracias constitucionais do Atlântico Norte, ele consegue afastar-se da ideia de uma política plenamente controlada por procedimentos democráticos e constitucionais com conceitos que se mostram 
produtivos no desafio de compreender a variedade do fenômeno político em diferentes regióes da sociedade mundial, inclusive os fenômenos que o conceito de "neopatrimonialismo" descreve. Estes conceitos podem ser utilizados para conduzir a teoria a romper com a idealizaçáo da política democrática e constitucional nos países de modernidade central e com a ideia de "neopatrimonialismo" enquanto indicador de atraso: refiro-me especialmente aos modos de diferenciação interna do sistema político em política, administração e púbico (LUHMANN, 2002, p. 253, grifos meus), associada à diferença centro/periferia e à constituiçáo de dois circuitos de poder paralelos, distintos e eventualmente contraditórios: o circuito formal e o circuito informal.

$\mathrm{Na}$ diferenciação interna do sistema, a política engloba processos, estruturas e atores dos poderes executivos e legislativos, mas também os partidos políticos envolvidos com a elaboração de decisôes coletivamente vinculantes. Não se trata de uma atividade que produz, isoladamente, decisóes coletivamente vinculantes, mas sim de comunicações que servem para preparar essas decisóes, testando e avaliando suas chances de sucesso (LUHMANN, 2002). A administração inclui todo o complexo de organizaçôes responsáveis por implementar leis, normas e regulamentos, oferecer serviços públicos e aplicar todo tipo de política pública ou programa formulados por decisóes políticas. Por fim, como resultado do acoplamento entre sistema político e sistema de comunicação de massas, surge uma esfera marcada pela auto-observação do sistema político, que serve como "espelho", no qual observaçóes sobre açóes e sobre outras observaçóes ganham relevância para a produçáo de decisóes coletivamente vinculantes: trata-se do público enquanto conjunto de discussóes que informam a opiniáo pública sobre temas politicamente relevantes e de papéis que os cidadãos podem assumir no sistema político, como: eleitor, membro de organização de interesse e movimentos sociais, contribuinte, beneficiário de programas sociais etc. $\mathrm{Na}$ forma de opinião pública, o público filtra os temas que interessam à produção de decisóes coletivamente vinculantes.

A diferenciação entre política, administração e público está associada à diferença interna centro/periferia (LUHMANN, 2002). Segundo esta diferença, o centro engloba os poderes executivos e legislativos, a 
administração pública e os partidos políticos, enquanto a periferia é composta pela opinião pública, os movimentos sociais, as organizaçóes de interesse, organizaçóes não governamentais etc. Com isso, a dicotomia ontológica entre Estado e sociedade civil (SAAVEDRA, 2020) é dissolvida e trabalhada como uma distinçáo produzida e controlada pelo próprio sistema político. Nesse sentido, Luhmann não reproduz, no plano da sociologia, a noção de Estado enquanto representação simbólica da unidade da diferença do sistema político, permitindo conceber as comunicaçóes políticas da "periferia" e do "público" como constitutivas para o sistema de preparação e produção de decisóes coletivamente vinculantes.

Enquanto os sistemas funcionais se apoiam na norma universalista da inclusão, deixando o "outro lado" da forma inclusão/exclusão fora de consideração, a diferenciação interna dos subsistemas funcionais produz uma variedade de organizaçóes, redes e outros níveis sistêmicos que produzem simultaneamente inclusão e exclusão, de acordo com lógicas e estruturas específicas, mas sempre com algum tipo de exclusão particularista. A combinação entre inclusão universalista nos sistemas funcionais com exclusão particularista em seus níveis e arenas internos se realiza, na política, especialmente com a bifurcação entre os fluxos do poder formal e do poder informal (LUHMANN, 1981b, 2002).

A distinção entre poder formal e informal não trata formas autocráticas, não constitucionais ou ilegais de inclusão e exclusão políticas como características exclusivas de determinados países (nacionalismo metodológico) considerados atrasados em sua trajetória de desenvolvimento, mas sim como características presentes, em maior ou menor grau, também em países definidos como democracias constitucionais, liberais e representativas. Ao trabalhar com a distinção entre poder formal e poder informal, Luhmann aborda a política não só para além do Estado e sua dimensão oficial, mas também para além do ideal constitucional de um poder político plenamente imune ao poder social desigualmente distribuído.

$\mathrm{Na}$ relação entre o público e a política, o poder formal é aquele que o cidadão transfere pelo voto ao governante, sendo, por definiçáo, normatizado, já que expressa a própria "constitucionalização do poder”. É precisamente este processo de "constitucionalização do poder" (NEVES, 2008, p. 481) que resulta na formação de direitos políticos igualitários como 
expressão da noção de soberania popular, concebida como fonte última de legitimação do poder na sociedade moderna. Na relação entre política e administração, o poder formal é a decisão sobre normas, leis, regulamentos, projetos, programas e políticas que os poderes executivos e legislativos produzem para serem implementados pela burocracia estatal. Na relação entre administração e público, o poder formal são as atribuiçóes relativas à implementação das decisóes políticas que ganham outro sentido na lógica organizacional própria da implementação.

O circuito do poder informal é uma espécie de fluxo comunicativo na direção oposta à do poder formal, e que floresce nas relaçóes de interdependência entre política, administração e público. Neste circuito, as comunicaçóes políticas não são alcançadas pela normatização constitucional, estabelecendo-se como um espaço que contrasta com a igualdade política normativamente esperada no espaço do poder formal. Trata-se de um circuito de poder que se tornou parte do dia a dia dos sistemas políticos modernos e no qual,

[...] a política não pode funcionar sem as orientações da administração. Assim como o público torna-se dependente da pré-seleção de pessoas e programas dentro da política e a administração passa a depender, na medida em que se expande para campos de forças mais complexos, da atuação voluntária do público, sendo obrigada a concedê-lo alguma influência. (LUHMANN, 198Ia, p. 164).

O espaço do poder informal ganha mais importância sempre quando a relaçáo entre a administração e o público, especialmente seu segmento organizado, adquire mais autonomia em relação às decisões políticas juridicamente controladas do parlamento e do Executivo. O crescimento e o adensamento das estruturas organizacionais envolvendo a administraçáo e o público, incentivados pela expansão do estado de bem-estar social, elevam a complexidade das situaçôes de decisão com as quais a administração se vê diariamente confrontada em função de suas relações informais com o público. Em geral, isto faz com que a administração torne-se cada vez mais dependente da cooperaçáo dos segmentos organizados do público, e do próprio mercado. Isto porque estes segmentos possuem uma margem de atuação e influência sobre a implementação de políticas públicas que não se deixa controlar pela cadeia de mando estatal juridicamente fixada, ou seja, pelo poder constitucionalizado e pelos programas decisórios oficiais: 
Segundo a imagem oficial, a administração toma decisões e as implementa independentemente do público afetado. A questão seria apenas o controle jurídico da decisão e de sua observância, ou seja, se apresenta como um problema do estado de direito e da vigilância de sua execução [...]. Na medida em que o estado de bem-estar social vai se desenvolvendo, a administração, por razões políticas, é cada vez mais incumbida de programas cuja execução depende da cooperação do público. Esta dependência, por sua vez, não pode ser mais controlada pelo direito ou por obrigações jurídicas; e também nem sempre está afinada com os interesses daqueles de cuja atuação conjunta depende a administração. Esta dependência refere-se mais a parceiros organizados com os quais se vai lidar novamente em outras constelações do que a indivíduos dotados de direitos subjetivos [...]. Na prática, isto cria uma complexa articulação de interesses à margem da legalidade e até mesmo para além de seus limites. Aquele de cuja cooperação depende a administração pode sempre exigir uma contrapartida. (LUHMANN, 2002, p. 260-26I).

Neste contexto, a oscilação entre partidos e grupos políticos no espaço do poder formal e constitucionalmente normatizado, por meio de eleiçóes periódicas, pode conviver com um espaço de poder informal mais ou menos rígido, no qual determinados setores, em geral os de maior poder econômico e capacidade organizativa, ao reunirem mais meios para sancionar negativamente a atuação da administração pública, conseguem controlar as melhores chances de influência sobre esta. O tipo extremo seriam os segmentos cujo volume de meios de sanção e poder sobre a administração os permite dissuadir qualquer resistência por parte desta, assim como todo tipo de concorrência por parte dos outros setores do público, organizados ou náo.

Nesse sentido, Luhmann permite romper com a idealização da política e da relação entre exclusão social e exclusão política para os países de modernidade central, fornecendo uma ferramenta muito melhor que o conceito de "neopatrimonialismo": a distinção entre poder formal e informal, ao contrário do conceito supracitado, não trata padróes de exclusão e inclusão políticas, bem como sua pré-estruturação social, como traços de regiôes específicas da sociedade mundial, mas como características intrínsecas da política moderna, capaz, no entanto, de assumir formas variadas em cada região.

Na próxima seção, discutiremos como a idealização que o conceito de neopatrimonialismo opera da modernidade política dos países centrais o torna inadequado para descrever a complexidade da política moderna, inclusive na periferia, especialmente a oscilação entre formas constitucionais democráticas e anticonstitucionais/autocráticas de estruturação e prática 
do poder político como traço da sociedade moderna como um todo, e não como singularidade nacional ou regional.

\section{A idealização do poder político constitucional e democrático}

O problema com o conceito de neopatrimonialismo é que ele confunde política funcionalmente diferenciada com política constitucionalizada, idealizando a relação entre política e sociedade no centro e construindo um contraponto comparativo empiricamente infundado para definir a condição da modernidade social e política em países como o Brasil. Como teoria da reflexão do sistema, ele tem relevância na aglutinação de forças políticas, mas como conceito científico; ao idealizar o seu pressuposto de comparação, perde aplicabilidade para entender a política e suas relaçóes com a sociedade.

Os problemas envolvendo a relação entre desigualdade social extrema e exclusão política não podem ser ignorados por nenhuma tradição de pensamento empenhada em refletir sobre os dilemas e as soluçóes da formação do Estado nacional entre nós. Na tradição que se desenvolveu em torno do conceito de patrimonialismo, a desigualdade e a exclusão sociais são percebidas como produto do caráter estamental da dominação política. O Estado neopatrimonial, ao restringir a livre manifestação de interesses e ao dificultar sua organização autônoma por meio das práticas de cooptação, favoreceria a reprodução das desigualdades sociais crônicas no país (SCHWARTZMAN, 1988). O problema estaria no caráter asiático e "oriental" do Estado, ou seja, na forma estamental do exercício do poder, segundo a qual os cargos e as funçôes estatais são tratados como patrimônio de quem os ocupa, a fim de obter vantagens dentro e fora da esfera política.

Seria o caráter "anticonstitucional" do poder político - que ignora tanto os direitos de cidadania como os "freios e contrapesos" destinados a impedir a colonizaçáo da sociedade e seus subsistemas pela política - a fonte das assimetrias e exclusóes encontradas na sociedade. $\mathrm{O}$ diagnóstico do domínio neopatrimonialista pode ser interpretado como constatação ou denúncia da (suposta) inexistência de diferenciação entre os principais subsistemas da sociedade, sobretudo entre política e economia. 
Os problemas fundamentais enfrentados e respondidos pela "linhagem patrimonialista" são aqueles derivados do esforço de constitucionalizar o acesso e o exercício do poder, ou seja, problemas que só existem porque a política se coloca o desafio de transformar a sociedade de acordo com as normas constitucionais da universalização da inclusão política e social, bem como das liberdades individuais correlatas da separação entre as esferas sociais.

Nessa perspectiva, a idealização do poder político constitucional operada pelo conceito de neopatrimonialismo implica a idealização da democracia enquanto única forma moderna de organizaçáo e operação do poder político. É, em síntese, a idealização da democracia constitucional como única variante moderna, sem equivalentes funcionais, para a construção de decisóes coletivamente vinculantes e aceitáveis como legítimas pelo público da política. Este discurso público e acadêmico sobre a relação entre democracia e as formas políticas autocráticas precisa ser revisto. Nesse sentido, é importante mencionar o trabalho de Santos (2017). O cientista político defende que o golpe parlamentar não pode ser explicado como um acontecimento de razão essencialmente distinto do sistema democrático, mas como um elemento intrínseco às democracias representativas (SANTOS, 2017). O autoritarismo não pode ser observado mais como um fato que não cabe no presente, como se fosse sobrevivência do passado, como exatamente prevê o conceito de neopatrimonialismo que tenta explicar o fechamento das posições de poder político pela herança do passado ibérico e patrimonialista.

$\mathrm{Na}$ teoria dos sistemas, Stichweh (2016) propóe considerar a política moderna, funcionalmente diferenciada em nível global, como oscilando atualmente de modo bipolar entre alternativas democráticas e autocráticas de organização e exercício do poder. Com isso, ele não só transcende a idealizaçáo constitucional da política já realizada por Luhmann como também permite análises comparativas de fenômenos autocráticos e democráticos sem nenhum tipo de "nacionalismo" ou "regionalismo metodológico", como encontramos no conceito de neopatrimonialismo. Como a política é um sistema global, diferenciado internamente em Estados-Naçôes, a pergunta que se coloca é a seguinte: no seu nível global, a política é democrática ou autocrática? Não existe a ideia de inclusão universal em 
Estado global simplesmente porque não existe um Estado global. Tudo o que a modernidade produziu em termos de democracia nunca alcançou o nível global em termos institucionais. $\mathrm{O}$ alcance foi apenas na semântica com a ideia de direitos humanos. Nos níveis subnacionais, é comum que regimes autoritários, a exemplo da China, combinem diferentes formas de inclusão e exclusão com a hierarquia interna da organização estatal e dos processos de tomada de decisóes coletivamente vinculantes. Assim, enquanto a conduçáo do governo central permanece inacessível, a implementação local de políticas públicas adquire mais abertura para a variedade de interesses e demandas do ambiente, promovendo formas distintas de participação da população afetada pelos resultados (output) das políticas governamentais (AHLERS; STICHWEH, 2019)13.

Essa concepção "bipolar" da política moderna a partir da teoria sociológica sistêmica nos permite um olhar mais nuançado sobre os processos de democratização ou de autocracia. Entre a possibilidade de retirar o rótulo de democrático e colocar o rótulo de autocrático, há um leque de gradações e de avanços dos enclaves autocráticos. A proposta é tratar democracia e autocracia como dois equivalentes funcionais de que dispóe a modernidade política, o que torna o conceito de neopatrimonialismo não só inaplicável como também inútil. Trata-se de uma releitura do que é a modernidade política: a democracia não é a única forma de tomada de decisões políticas - existe uma série de decisóes, inclusive com o apoio da coletividade, que são tomadas priorizando critérios, como eficiência econômica e rapidez, que desqualificam qualquer pretensão sociologicamente informada de um poder político plenamente democrático e constitucional. A política moderna não pode ser reduzida à democracia. Não podemos transformar o ideal normativo da democracia em valor universal. A nossa realidade social é multivalorativa: existe um pluralismo de valores inerente à diferenciação

I3 Cui Zhiyuan (2008) sugere uma análise multinível muito semelhante ao modelo de Ahlers e Stichweh, 2019. Ele destaca a necessidade de observar déficits e realizações democráticas nos diferentes níveis de constituição do Estado chinês, e assim como Ahlers e Stichweh aponta a coexistência de autocracia no nível do poder central, controlado exclusivamente pelo partido, com métodos democráticos de seleção de lideranças nos níveis locais. Estes métodos têm a ver especialmente com a influência rotineira institucionalizada de pesquisas de opinião pública sobre a seleção de governantes e com a inclusão administrativa em experimentos e política econômica e social. 
funcional da sociedade e isto leva a que o valor da democracia nem sempre seja o valor preferido pelas maiorias. Às vezes, a maioria prefere um regime autoritário; mas, que seja eficiente para tomar decisóes. Este fenômeno é especificamente moderno, nada tendo a ver com neopatrimonialismo; afinal, o que está em jogo é o princípio moderno de legitimação das decisóes perante um público. Este público, nos regimes autocráticos, não tem o status de estamento inferior sem qualquer ligação com o poder possuído de modo doméstico pelo estamento superior, mas sim de um público levado em conta por quem controla o poder do estado, ainda que de modo passivo. As diferentes formas modernas de autocracia acolhem, seletivamente, o imperativo da inclusão do público, mas sem sua participação na seleção das elites políticas. Assim, a ditadura militar brasileira, por exemplo, deixa de ser evidência empírica da tese do neopatrimonialismo, para demonstrar a variação bipolar da política moderna.

\section{Conclusão}

Neste texto, tentamos demonstrar como o conceito de neopatromonialismo, apesar de suas inovaçóes em relação ao conceito de patrimonialismo, não rompe com a idealização da modernidade como um todo e da modernidade política, em particular. $\mathrm{Na}$ análise orientada pelo conceito de neopatrimonialismo, estruturas informais de poder como as que sustentam o caráter relativamente mais autocrático da política em países da América Latina como o Brasil são percebidas como incompatíveis com a modernidade política, idealizada como política democrática e constitucional.

Esta comparação baseada em premissas idealizadas sobre a modernidade política é a fonte permanente de teses sobre a "singularidade brasileira" (TAVOLARO, 2014), nas quais problemas que não cabem na moldura idealizada da modernidade são tratados como sobrevivência do passado específico de um país ou regiáo. Nesse quadro, a reprodução de estruturas informais, excludentes e autocráticas de poder não pode ser observada como elemento genuíno da modernidade política, presente, com intensidade e amplitude variáveis, em todas as regiōes e países.

Nosso argumento é que, ao substituir a visão idealizada da modernidade política que reduz a política moderna à sua dimensão democrática e consti- 
tucional por concepçôes que levam em conta a dimensão não constitucional e não democrática, o conceito de neopatrimonialismo perde aplicabilidade e utilidade. Isto acontece porque todas as contradiçóes como a misturas de interesses privados com interesse público, fechamento persistente e autocrático do acesso ao poder, exclusão política que o conceito precisava descrever como elementos não modernos sobreviventes ao moderno agora podem e precisam ser descritas como dimensão constitutiva da modernidade política.

É exatamente esta noção complexa da modernidade política que a sociologia política de Luhmann oferece ao descrever a política moderna, funcionalmente diferenciada, como dividida em dois circuitos de poder: um circuito formal e constitucional e outro informal e não constitucional do poder. Nesta concepção, o poder informal e não constitucional é exercido, sobretudo, por setores organizados da sociedade, dos quais a administração pública depende para implementar seus programas. Embora reforce desigualdades sociais por meio do acesso desigual ao poder, o poder informal não é exercido, de modo necessário, por nenhum grupo social unitário que possa ser definido como o "topo" ou "centro" da sociedade como ocorria em sociedades estamentais, tal como descritas tanto por Luhmann como por Weber. O controle do poder político por uma estrutura unitária de dominação é um elemento necessário ao conceito de neopatrimonialismo. Tanto Weber como Luhmann, ao analisarem a constituição da política como esfera de valor ou como subsistema funcional, afirmam que este tipo de controle por uma estrutura unitária de dominação tida como necessária é impossível em condições de diferenciação das esferas e subsistemas funcionais. Neopatrimonialismo pressupóe uma estrutura unitária de desigualdades, ou seja, a não diferenciação da sociedade (SCHWINN, 2011); por isso, é incompatível com a política moderna.

É preciso abdicar da premissa sobre a "singularidade" de países ou regiôes em relação a processos de controle estamental, não constitucional e informal do poder, destacando como estes processos também ocorrem em países da modernidade tida como central. O conceito de neopatrimonialismo está atado a uma visão empiricamente e teoricamente insustentável da modernidade política, que idealiza a dimensão democrática e constitucional do poder político e ignora ou negligência sua dimensão autocrática e 
não constitucional. A globalização da bipolaridade política moderna entre autocracia e democracia (STICHWEH, 2016) exige ferramentas analíticas capazes de perceber a relação constitutiva entre os polos estruturais e ideológicos que formam os paradoxos da política moderna com suas promessas não realizadas de inclusão universal ilimitada. $\mathrm{O}$ conceito de neopatrimonialismo não é capaz de cumprir esta tarefa.

\section{Referências}

AHLERS, A. L.; STICHWEH, R. (2019), "The bipolarity of democracy and authoritarianism: value patterns, inclusion roles and forms of internal differentiation of political systems". Sociologia e Antropologia, vol. 9, n. 3, p. 819-846, 2019.

ANDERSON, B. Imagined Communities. Reflections on the Origin and Spread of Nationalism. Londres: Verso, 2006.

BACHUR, J. P. A performatividade da exclusão e as lutras por inclusão: questóes distributivas a partir da teoria dos sistemas sociais. Sociologia e Antropologia, Rio de Janeiro, v. 10, n. 1, p.129$153,2020$.

BAYLY, C. The Birth of Modern World 1780-1914. Global Connections and Comparisons. Londres: Blackwell, 2004.

BENDIX, R. Work and authority in industry. New York: John Willy \& Sons, 1956.

BRITO, L. O. B. Brasil: oriente político. Uma discussão sobre o patrimonialismo estatista. Orientador: Bernardo Ricupero. 2015. 192 f. Dissertação (Mestrado em Ciência Política) Programa de Pós-Graduação em Ciência Política, Universidade de São Paulo, São Paulo, 2015.

BOTELHO, A. Sequências de uma sociologia política brasileira. Dados - Revista de Ciências Sociais, Rio de Janeiro, v. 50, n. 1, p. 49-82, 2007.

BOURDIEU, P. O campo político. Revista Brasileira de Ciência de Ciência Política, Brasília, n. 5, p. 193-216, 2011.

BOURDIEU, P. Sobre o estado. São Paulo: Cia das Letras, 2014.

CADENAS, H.; MASCAREÑO, A. Lineamientos para una sociología evolutiva da la diferenciación funcional em América Latina. Sociologia e Antropologia, Rio de Janeiro, v. 10, n. 1, p. 75-98, 2020 .

CARDOSO, F., Capitalismo e escravidáo no Brasil meridional: o negro na sociedade escravocrata do Rio Grande Sul. Rio de Janeiro: Civilização Brasileira, 2003.

CARVALHO, J. A Construçáo ordem/teatro das sombras. Rio de Janeiro: Civilizaçáo Brasileira, 2008.

DIAS, F. C. Presença de Max Weber na sociologia brasileira contemporânea. Revista de Administração de Empresas, São Paulo, v. 1, n. 4, p. 47-62, 1974. 
DOMINGUES, J. A sociologia de Talcott Parsons. Niterói: UFF, 2001.

DOMINGUES, J. M. Patrimonialismo e neopatrimonialismo. In: ARVRITZER, L. (org.). Corrupçáo: ensaios e críticas. Belo Horizonte: UFMG, 2008. p.187-192.

DOMINGUES, J. Teoria crítica e semi (periferia). Belo Horizonte: UFMG, 2011.

DOMINGUES, J. Esquerda: crise e futuro. Rio de Janeiro: Maud, 2017.

DUTRA, R. Diferenciação funcional e a sociologia da modernidade brasileira. Política \& Sociedade, Florianópolis, v. 15, n. 34, p. 77-109, 2016.

DUTRA, R. Por uma sociologia sistêmica pós-colonial das diferenças no interior da sociedade mundial moderna. Sociedade e Estado, Brasília, v. 35, n. 1, p. 259-285, 2020.

EISENSTADT, S.N. Tradicional patrimonialism and modern neopatrimonialism. London: Sage Publications, 1973.

FAORO, R. Os donos do poder: formação do patronato político brasileiro. Porto Alegre; São Paulo: Globo, [1975] 2008.

FERNANDES, F. A revoluçáo burguesa no Brasil: ensaio de interpretação sociológica. São Paulo: Globo, 2006.

GOSWAMI, M. Rethink the Modular Nation Form: Toward a Sociohistorical Conception of Nationalism. Comp. Stud. Soc. Hist., n. 44, p. 770-799, 2002.

HILL, C. National History and the World of Nations. Capital, State and the Rhetoric of History in Japan, France and United States. Durham; Londres: Duke University Press, 2008.

HOLANDA, S. Raízes do Brasil. São Paulo: Companhia das Letras, [1936] 1995.

LUHMANN, N. Machtkreislauf und Recht in Demokratien. Zeitschrift für Rechtssoziologie, 1981a.

LUHMANN, N. Politische Theorie im Wohlfahrtsstaat. Analysen und Perspektiven. München; Wien: Olzog, 1981b.

LUHMANN, N. Gesellschaftsstruktur und Semantik: Studien zur Wissenssoziologie der modernen Gesellschaft. V. 3 Frankfurt a.M: Suhrkamp, 1989.

LUHMANN, N. The Future of Democracy. Thesis Eleven, v. 26, n. 1, p. 46-53, 1990.

LUHMANN, N. Die Gesellschaft der Gesellschaft. Vol. 1 e 2. Frankfurt a. M: Suhrkamp, 1997.

LUHMANN, N. Die Politik der Gesellschaft. Frankfurt am Main: Suhrkamp, 2002.

LUHMANN, N. Politische Soziologie. Berlin: Suhrkamp, 2010. MORSE, R. A Miopia de Schwartzman. Novos Estudos, São Paulo, n. 24, p. 166-178, 1989.

NEVES, M. Verfassung und Öffentlichkeit. Zwischen Systemdifferenzierung, Inklusion und Anerkennung. Zeitschrift für Staatslehre und Verfassungsgeschichte deutsches und europäisches öffentliches Rechts, n. 4, p. 477-509, 2008. 
PAIM, A. A Querela do Estatismo. Brasília: Senado Federal, 1998.

RIBEIRO, M. A. F. Autoritarismo e democracia no pensamento político de Raymundo Faoro, Simon Schwartzman e Fernando Henrique Cardoso. Campos dos Goytacazes. Orientador: Wania Amélia Belchior Mesquista. 2010. 337f. Dissertação (Mestrado em Sociologia Política) Programa de Pós-Graduação em Sociologia Política, Universidade Estadual do Norte Fluminense Darcy Ribeiro,Campos dos Goytacazes , 2010.

SAAVEDRA, M. E. El concepto sistémico de lo político. Un esbozo. Sociologia e Antropologia, Rio de Janeiro, v. 10, n. 1, p. 99-128, 2020.

SANTOS, W. G. A democracia impedida: o Brasil no século XXI. Rio de Janeiro: FGV, 2017.

SCHNEIDER, W. L. Systemtheorie, hermeneutische Tradition und die TheoriesozialerDifferenzierung. In: RENÉ, J. et al. (org.). Die Methodologien des Systems. Wie kommt man zum Fall und wie dahinter? Wiesbaden: VS Verlag, 2010. p. 203-224.

SELL, C. Leituras de Weber e do Brasil: da política à religiáo, do atraso à modernidade. Ciências Sociais Unisinos, São Leopoldo, v. 43, n. 3, p. 241-248, 2007.

SELL, C. Max Weber e a racionalizaçáo da vida. Petrópolis: Vozes, 2013.

SELL, C. As duas teorias do patrimonialismo. In: ENCONTRO DA ASSOCIAÇÃO BRASILEIRA DE CIÊNCIA POLÍTICA (ABCP), 10, sexta-feira, 2 de setembro de 2016. Anais eletrônicos Anais do $10^{\circ}$ Encontro da ABCP. Disponível em: https://cienciapolitica.org.br/system/ files/documentos/eventos/2017/04/duas-teorias-patrimonialismo-max-weber-1070.pdf. Acesso em: 20 mar. 2019.

STICHWEH, R. Politische Demokratie und die funktionale differenzierung der gesellschaft zur logic der modern. Fiw working paper n. 3. Rheinische Friedrich-Wilhelms-Universität Bonn Forum Internationale Wissenschaft., Bonn, Alemanha, 2016.

SCHWARTZMAN, S. São Paulo e o Estado Nacional. São Paulo: Difel, 1975.

SCHWARTZMAN, S. Bases do Autoritarismo Brasileiro. 2 ed. Rio de Janeiro: Campus, 1988.

SCHWARTZMAN, S. A Atualidade de Raymundo Faoro. Dados - Revista de Ciências Sociais, Rio de Janeiro, n. 2, p. 207-213, 2003.

SCHWINN, T. Differenzierung ohne Gesellschaft: Umstellung eines soziologischen Konzepts. Weilerswist: Velbrück Wissenschaft, 2001.

SOUZA, J. A ética protestante e a ideologia do atraso brasileiro. In: SOUZA, J. (org.). O malandro e o protestante: a tese weberiana e a singularidade cultural brasileira. Brasília: Unb, 1999. p.17-54.

SOUZA, J. A construçáo social da subcidadania: para uma sociologia política da modernidade periférica. Belo Horizonte: UFMG, 2003.

TAVOLARO, S. A tese da singularidade brasileira revisitada: desafios teóricos contemporâneos. Dados - Revista de Ciências Sociais, Rio de Janeiro, n. 3, p. 633-73, 2014. 
URICOECHEA, F. O Minotauro Imperial: A Burocratização do Estado Patrimonial Brasileiro no Século XIX. Rio de Janeiro: Difel, 1978.

VILLAS BÔAS, G. A recepçáo controversa de Max Weber no Brasil (1940-1980). Dados Revista de Ciências Sociais, Rio de Janeiro, n. 1, p. 5-33, 2014.

WERNECK VIANNA, L. Weber a Interpretação do Brasil. Novos Estudos, São Paulo, n. 53, p. 33-47, 1999.

WERNECK VIANNA, L. Raymundo Faoro e a difícil busca do moderno no país da modernização In: BOTELHO, A.; SCWARCZ, L. (org.). Um enigma chamado do Brasil: 29 intérpretes e um país. São Paulo: Companhia das Letras, 2009. p.364-377.

ZHIYUAN, C. Seminário Instituiçóes para Inovaçáo (Rio de Janeiro: 2008). Reflexôes sobre uma agenda de desenvolvimento para longo prazo. Brasília: Presidência da República, 2009. Disponível em: http:/www.biblioteca.presidencia.gov.br/publicacoes-oficiais/catalogo/lula/ instituicao-para-inovacoes-2009/@@download/file/Instituicao\%20para\%20Inovacoes\%202009. pdf. Acesso em: 22 maio 2020.

Recebido: 07/08/2019

Aceito: 18/06/2020 


\section{Neopatrimonialism, functional differentiation and the center- periphery relationship revisited}

\section{Abstract}

This article aims to deny the theoretical validity of the concept of neopatrimonialism, formulated by Simon Schwartzman, in order to understand the dilemmas of political exclusion in contemporary Brazil, since the concept is based on an apologetic reading of Max Weber's diagnosis about the West. From the bibliographical analysis, we argue that the concept of neopatrimonialism is stuck to an empirical and theoretically unsustainable vision of political modernity, which idealizes the democratic and constitutional basis of modern political power and ignores its autocratic dimension and non-constitutional. Next, we present as a theoretical alternative the political sociology of Niklas Luhmann, for it describes modern politics as divided in the circuits of formal and constitutional power, and informal and non-constitutional. In this way, we can analyze the processes of political exclusion in the center and in the periphery without the presence of idealizations about the central countries.

Keywords: Neopatrimonialism. Differentiation of society. Political Modernity. Exclusion. 